\title{
Global-local dynamics in the transformation of the Jakarta metropolitan area into a global city-region
}

\author{
Galuh Syahbana Indraprahasta ${ }^{1,2, *}$, Ben Derudder $^{1}, \&$ Jorn Koelemaij $^{1}$ \\ ${ }^{1}$ Department of Geography, Ghent University, Krijgslaan 281 (S8), B-9000 Ghent, Belgium \\ ${ }^{2}$ Pappiptek, Indonesian Institute of Sciences (LIPI), PDII-A Building, J1. Jend. Gatot Subroto 10, \\ Jakarta 12710, Indonesia \\ *galuhsyahbana.indraprahasta@ugent.be, galuh.indraprahasta@gmail.com
}

To cite this article: Galuh Syahbana Indraprahasta, Ben Derudder \& Jorn Koelemaij (2018)

Global-Local Dynamics in the Transformation of the Jakarta Metropolitan Area into a Global City-

Region, disP - The Planning Review, 54:3, 52-62, DOI: 10.1080/02513625.2018.1525212

To link to this article: https://doi.org/10.1080/02513625.2018.1525212.

\begin{abstract}
This paper investigates the way in which factors at the global and local level interact in the emergence and development of 'global city-regions', which are deemed to be the contemporary growth machines of the global economy. To this end, this paper takes the Jakarta metropolitan area (JMA) as a case to investigate its evolution in the context of the intertwined dynamics of foreign direct investment (FDI) inflow and state intervention over the past three decades. The findings indicate that, from a macrolevel perspective, the JMA has maintained its position as the country's hotspot for manufacturing investment embedded in East Asian production networks. In addition, we find that the national state has continuously privileged the JMA as the main grounds for national economic development in spite of the country's shifting political system. We reveal how the nexus between 'global' forces (incoming FDI) and 'local' conditions (the state's strategic intervention) has led to the development and restructuring of the JMA as a global city-region.
\end{abstract}

\section{Introduction}

Recent discussions on the geographical implications of contemporary economic globalization pay a considerable amount of attention to the increasing importance of large city-regions in both developed and developing countries (Florida, Gulden, \& Mellander, 2008; Harrison \& Hoyler, 2015; Jones \& Douglass, 2008; Pain, 2012). These 'global city-regions' (Scott, 2001a, 2001b) - various terms with slightly different connotations are used in the literature - have come to the fore as the building blocks 
of the global economy: they are the 'basic motors' (Scott, 2001b: 4) of global economic growth, and typified by 'the leading-edges of the contemporary post-Fordist economy', including high-tech production and manufacturing, advanced business services, and cultural industries (Scott, 2001a: 818). Morphologically, a global city-region (GCR) refers to an urban agglomeration comprising 'one or any contiguous sets of metropolitan areas together with surrounding hinterlands as well as synergynetworks of medium-size cities' (Scott, 2001b: 4). As such, GCRs are not only internally strongly interconnected, but also the key sites through which global economic integration play out (Pain, 2012).

The genesis of GCRs was largely triggered by the global economic restructuring that began to unfold in the 1970s, characterized by a 'global shift' in the activities of transnational corporations (TNCs) (Dicken, 2011; Scott, 2001a, 2001b). This crisis-generated process has forced TNCs to relocate parts of their production to developing countries, thus giving rise to the new international division of labour (NIDL). Benefiting from a concentration of flexible production systems and a close proximity to the world market, major metropolises across the world emerged as the prime locations for global capital accumulation under the NIDL. As a corollary, these urban areas have experienced profound spatial and economic transformations, which reflect their functional integration in the capitalist world system (Friedmann, 1986). Following the deindustrialization process and post-industrial economic transitions, major metropolises in advanced economies have increasingly become the management centres of the global production system and, accordingly, gradually relied on producer services as their major economic mainstay (Kloosterman \& Lambregts, 2007; Pain, 2008). Meanwhile, the urban dynamism of many large cities in transition economies, primarily in East Asia, became closely related to rapid industrialization processes (Hudalah et al., 2013; Zhao \& Zhang, 2007). In this context, it is unsurprising that analyses of the contemporary socio-economic transformation of major urban regions across the globe have been situated in light of the wider dynamics of economic globalization (Derudder et al., 2012; Taylor et al., 2013).

In spite of the wholesale emergence of GCRs as the spatial expression of current worldwide economic transformations, the development of cities and regions obviously plays out very differently in different local (national and urban) contexts (Kloosterman \& Lambregts, 2007; Roy, 2009). As such, a nuanced understanding of contemporary urban transformations should also take cities' (or cityregions') specific local conditions into consideration, including the role of specific national and urban actors. In particular, a growing body of scholarship puts forward that, rather than passively adopting the outcomes of globalization, (national) state actors may indeed actively participate in the urbanization process and GCR-formation in multiple ways, thus filtering and shaping the impacts of globalization on urban-regional development (Douglass, 2000; Hill \& Kim, 2000; Olds \& Yeung, 2004; Wu \& Barnes, 2008). By focusing on an empirical study of the Jakarta metropolitan area 
(JMA), the present paper seeks to investigate how factors at the 'global' and 'local' level interact in the emergence and development of the JMA.

The JMA is both the largest urban population concentration and economic agglomeration in Indonesia (Rustiadi et al., 2015). From a macro perspective, a number of studies - particularly under the world city network research agenda - have identified Indonesia's largest metropolis as one of the strategic nodes of the global economy (e.g. Taylor et al., 2014; Wall \& van der Knaap, 2011; Yang et al., 2017). The JMA is essentially an urban region encompassing the capital province of Jakarta and its adjacent peri-urban areas of Bogor (District and Municipality), Depok Municipality, Bekasi (District and Municipality) in West Java Province, and Tangerang (District and Municipality) and South Tangerang Municipality in Banten Province.

Since the late 1980s, Indonesia has shifted its economic regime from inward-looking towards a more open and liberalized economy that embraces global capitalism. As in many other developing countries, attracting foreign direct investment (FDI) has been the major way in which the country has connected with the wider global economy (Lipsey \& Sjöholm, 2011; Sit, 2001). FDI has, in turn, become a central global force underlying the spatial and structural transformation of Indonesia's major cities, particularly the JMA. Earlier studies, conducted in the 1990s, revealed how inbound FDI has inserted the JMA into the global economic system and, accordingly, led to its rapid urban transformation (Firman, 1998; Soegijoko, 1996). However, at the same time, it is important to note that since then Indonesia, and specifically the JMA, witnessed major political and economic shocks: two financial crises at the global level and a major political restructuring at the national level. Against this backdrop, this paper aims to examine the global-local dynamics underlying the JMA's recent urban transformation through the lens of changing FDI inflows and shifting state intervention.

The remainder of this article consists of four parts. The first part examines the characteristics and dynamics of FDI that have been attracted to the JMA. The second part discusses shifting patterns of state intervention and how this relates to the accumulation of FDI in the JMA. The third part uncovers the implications of the interplay between FDI inflow and state intervention for the JMA's transformation as a GCR. The final part briefly summarizes the main findings.

\section{FDI and the JMA's integration into the global economy}

The widespread restructuring of the capitalist global economy that started in the 1970s has in many ways spurred East Asian economic dynamics, typified by gradual processes of industrial transfer and economic transformation across countries within the region (Lo \& Yeung, 1996). Triggered mainly by the structural economic transformations of and in Japan, this process was later followed by the newly 
industrialized economies (NIEs) of South Korea, Hong Kong, Taiwan, and Singapore. Urata (1993) notes that the second half of the 1980s marked a massive expansion of FDI, mainly flowing from Japan and the NIEs to East Asian emerging economies, including Indonesia, in search of places having much lower production costs. In addition, Indonesia's increasing integration into the global economic system was also largely enabled by the changing attitude of the national state embracing a more liberal policy stance regarding industry and trade. Hill (1988) documented that since the adoption of liberalization measures of the late 1980s, Indonesia has increasingly enjoyed a boom period of FDI influx. Among the major metropolises in Indonesia, most large-scale manufacturing FDI was concentrated in the JMA. As a result, since the late 1980s, the JMA has witnessed an accelerating pace of industrial-led urbanization (Firman, 1998; Soegijoko, 1996).

In this section, we discuss how the JMA's exposure to the global economy has evolved after the late 1980s through the lens of the dynamics of FDI inflow. To this end, we concentrate mainly on three FDI attributes: sector, country of origin, and geographical dispersion. To clarify these changing patterns, the discussion is framed into three sequential time-periods: (1) 1990-1997, known as the boom period of manufacturing industries, (2) 1998-2008, which signifies the period between two financial crises, and (3) 2009-2014, the period after the global financial crisis.

The early years of the 1990s essentially reflected Indonesia's deepening integration into the global economy. Being the country's major economic centre, the JMA captured more than 50\% of cumulative FDI inflows to Indonesia between 1990 and 1997. Signposted as the beginning of an era of export-led industrialization, manufacturing FDI accounted for about $87 \%$ of the JMA's cumulative FDI during 1990-1997 (Figure 1).

These export-led industries were primarily fuelled by the rapid production growth of low-skill labourintensive products, such as textile, garment, and footwear, which at that time were also the country's prime industries (Thee, 2005). However, given the intense price competition from other low-wage Asian countries, most notably China, Vietnam, India, and Bangladesh, these industries later became less competitive (Thee, 2000: 421-22). The outbreak of the Asian financial crisis (AFC) in 1997, which brought the country into a deep multidimensional crisis, added even more severe damage to these industries. Compared to the other affected countries such as South Korea, Thailand, Malaysia, and the Philippines, the Indonesian economy experienced the worst impact, and the JMA, in particular, was hit hardest (Hill, 1999). In addition, foreign investors' confidence plummeted because of the socio-political and economic uncertainty in the aftermath of the crisis (Firman, 2002). As a result, from 1996 to 2001, the amount of FDI inflow stagnated, with fluctuating levels and only a few minor annual increases that were minor compared to the previous booming period that lasted until 1993 (see Figure 1). 
Although FDI inflow into the JMA in the early 2000s saw a clear increase, it was mainly generated by the services sector, with manufacturing industries still experiencing sluggish performance due to the prolonged economic crisis (Thee, 2000). Apart from the national manufacturing turmoil, the increase of the services sector was in part related to the liberalization policy of some service sub-sectors, notably enacted through the Government Regulation 20/1994 on Shareholding of Company under the Framework of Foreign Investment. At a broader scale, however, this increase corresponds to a more encompassing increasing trend of FDI in services flowing into developing countries (UNCTAD, 2015: 25).

After more than a decade of relative stagnation, from 2010 onwards manufacturing FDI inflow into the JMA started rising again. One notable factor was the enhanced political stability and the economic recovery in the last couple of years. As Tijaja and Faisal (2014) argue, the improvement of the country's overall political and economic conditions has served as a basis for the state to bring industrial development back on to the national agenda. For example, in 2007 the national state introduced Law 22/2007 on the Long-Term National Development Plan (RPJPN) 2005-2025, which identifies the industrial sector as the engine of growth for strengthening the national economy.

Over the entire period 1990-2014, one can also witness variations in terms of incoming manufacturing FDI within the JMA. High-tech industries, such as automotive and electronic industries, have gradually emerged in conjunction with the demise of low-tech sectors. In fact, this shifting pattern reflects the broader national industrial restructuring, in which knowledge-intensive industrial products have become increasingly significant as the country's main products for export in recent years (MOI, 2016).

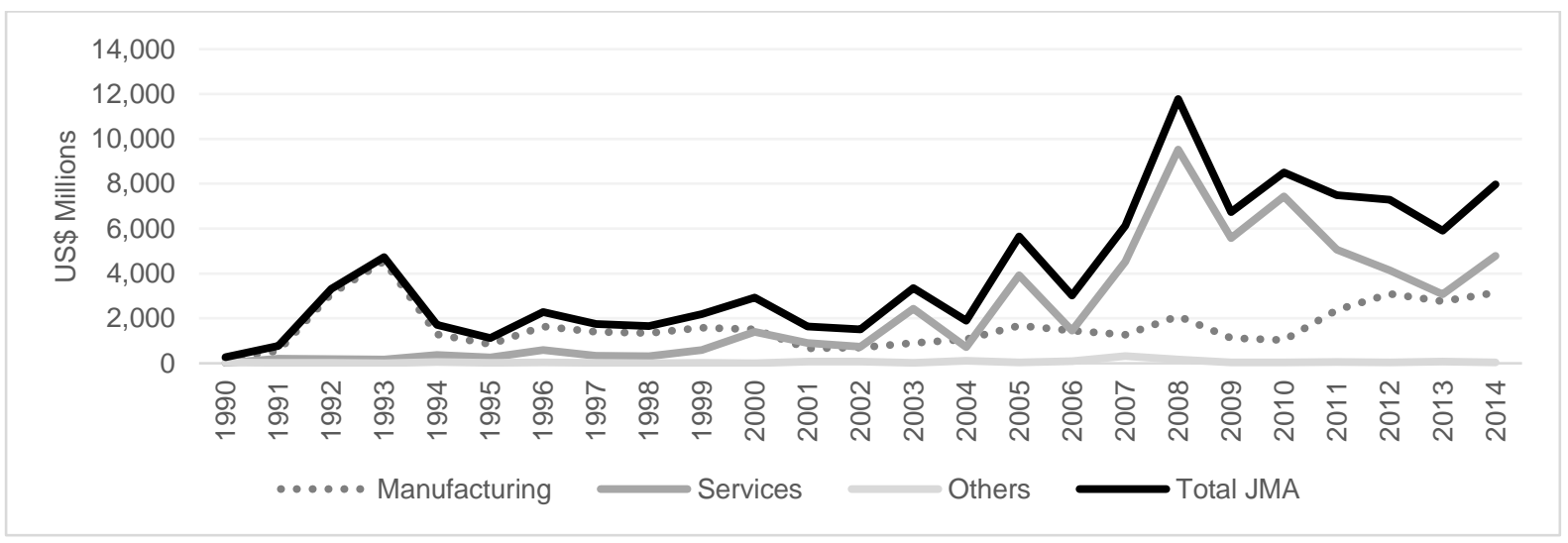

Figure 1 FDI inflow into the JMA

Source: Analysis based on BKPM, 2015 
From the perspective of the sources of FDI, the pattern of countries of origin continues to illustrate the regional economic geography in which the JMA is embedded: it remains dependent on FDI from East Asia. Figure 2 clearly demonstrates that East Asian countries have increasingly supplied the largest volume of cumulative FDI to the JMA, from 64\% in 1990-1997 to $66 \%$ in $1998-2008$ and $72 \%$ in 2009-2014. Japan, once a dominant FDI source for the JMA in the early 1990s, has been gradually surpassed by Singapore. The relatively declining contribution of Japan could be explained by the fact that, in general, Japanese FDI, mainly in manufacturing, has shifted from Southeast Asian countries to China (Hamanaka, 2011). Meanwhile, the rising investment from Singapore indicates its role as the region's strategic hub, which it has continued to fulfil since the 1990s, when low-end manufacturing activities were outsourced to other countries and regions and the city-state became specialized as being the NIDL's management and knowledge centre as well as the logistic hub of Southeast Asia (Yeung, Poon, \& Perry, 2001; see also Thomsen, Otsuka, \& Lee, 2011: 12). Interestingly, outside the East Asian countries, the Netherlands has constantly been a major source of FDI for the JMA. This European country even showed an increasing share from 3\% in 1990-1997, to $12 \%$ in 2009-2014. The Netherlands' particular interest to retain its investment in the JMA, and in Indonesia in general, can of course be attributed to its past colonial ties with Indonesia (see van der Eng, 1998).

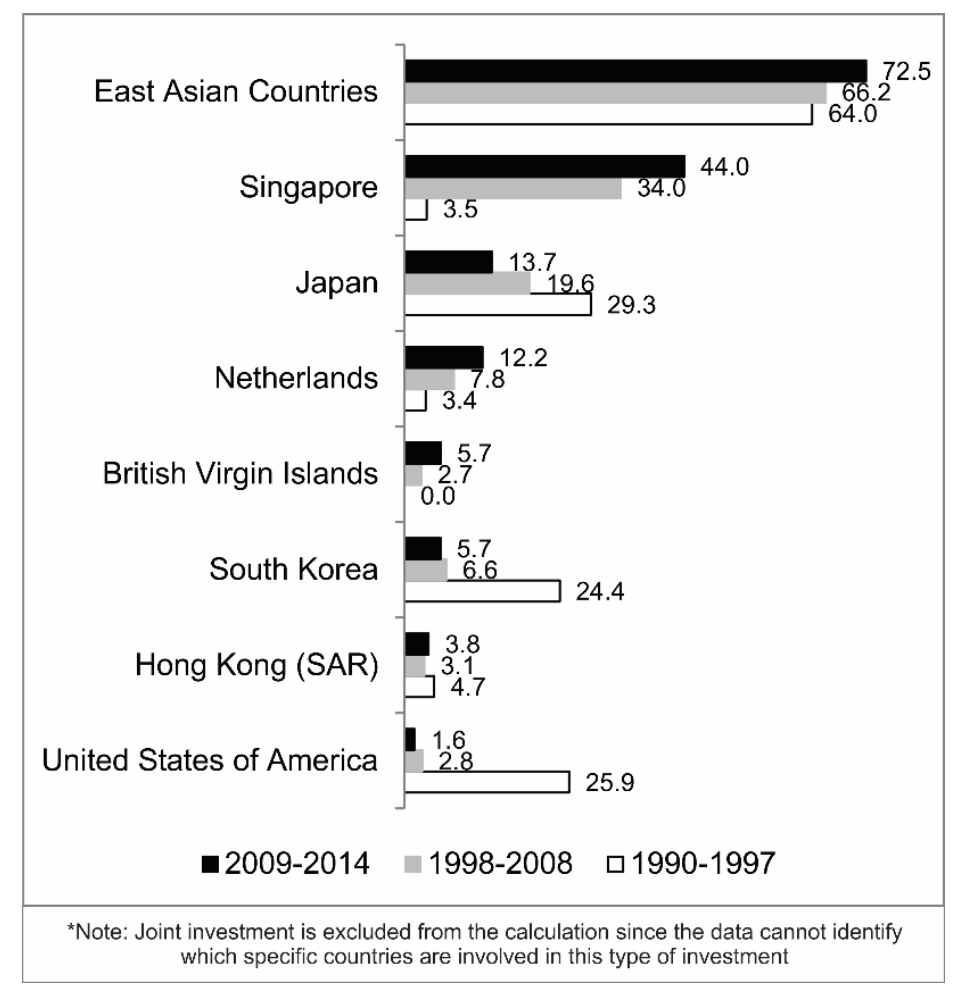

Figure 2 Largest countries of origin of FDI (\%)

Source: Analysis based on BKPM, 2015

In the meantime, the spatial economy of the JMA itself also faced some noteworthy changes within this period (Figure 3). For this reason, the aforementioned sectoral shifts within these FDI connections 
have been very location-selective. During the peak period of the 1990s' manufacturing boom, the city of Jakarta itself for instance still attracted a significant amount of manufacturing FDI, accounting for about $44 \%$ of the JMA's cumulative FDI in manufacturing. Meanwhile, the rest of the manufacturing FDI was unevenly distributed within the peri-urban areas, mostly concentrated in Bogor Municipality and Bekasi District. After the 1997 AFC, however, the spatial distribution of FDI inflows underwent a gradual transformation. On the one hand, manufacturing FDI has continuously decentralized from Jakarta to the metropolitan outskirts, largely flowing towards the private industrial estates that have been established since 1989 (World Bank, 2012). On the other hand, the increasing influx of services FDI has tended to concentrate in Jakarta instead. Between 2009-2014, Central and South Jakarta alone attracted about $88 \%$ of the JMA's cumulative FDI in the services sector. These two districts are commonly referred to as the Central Business District (CBD) of Jakarta, within which most of important international and national offices, large commercial centres, and upper-class residential blocks are located.

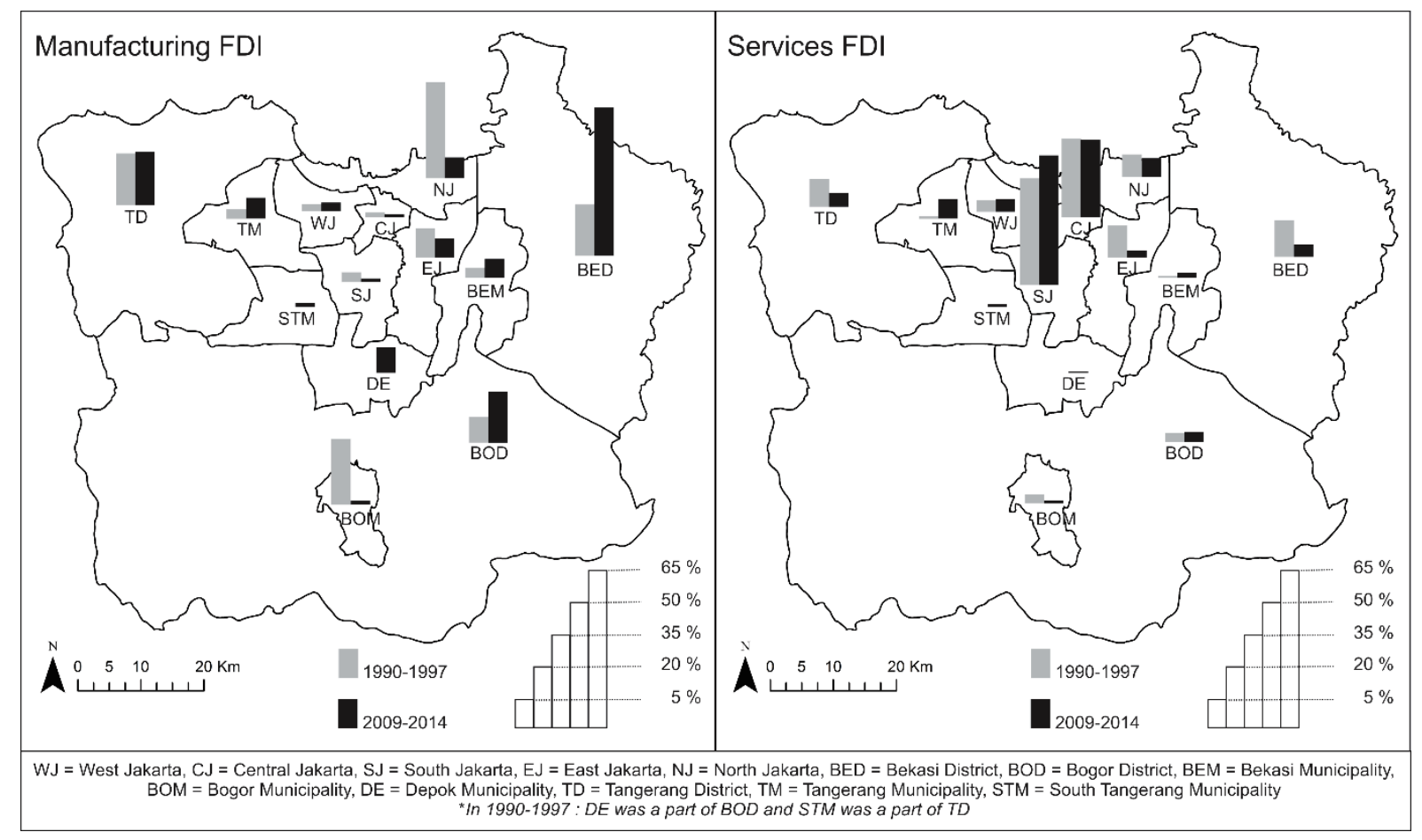

Figure 3 Geographical shift in manufacturing and services FDI

Source: Analysis based on BKPM, 2015

\section{State intervention: FDI accumulation and repositioning the JMA within the national urban system}

As previously argued, the formation of a GCR is the intertwined result of factors at the global and local level. The shifting FDI patterns as a result of external economic changes, therefore, were not the sole driver behind the spatial-economic development of the JMA. In this section, we therefore discuss 
how national state intervention has facilitated and steered FDI inflows through strategic spatiallybased policies and megaproject developments (see Wei, Leung, \& Luo, 2006; Wu \& Barnes, 2008).

Prior to the outbreak of the AFC in 1997, or more generally during the authoritarian regime of President Soeharto (1967-1998), Indonesia's national development was highly centralized and embraced a paradigm positioning Jakarta as its primary growth centre. It is therefore unsurprising that Jakarta's urban development generally resembled the country's national development and its economic progress. In particular, as the national state started to emphasize industrialization as one of the country's key agendas to boost economic growth in the 1970s, Jakarta concurrently emerged as an important industrial hotspot (Sedyawati et al., 1986). The national industrial development was endorsed at first in the industrial zones (zona industri), referring to 'a concentration of industrial activities that are not necessarily supported by planned and adequate infrastructure and facilities' (Hudalah \& Firman, 2012: 44), and later in industrial estates (kawasan industri). Jakarta Industrial Estate Pulogadung (JIEP) in East Jakarta was, indeed, the first industrial estate established by the national state in 1973 as a part of a wider industrial development programme (Kwanda, 2000). With the existence of large industrial concentrations in both industrial zones and estates, Jakarta appeared as the country's primary location for FDI-led industrial development from the 1970s to the 1980s (Henderson, Kuncoro, \& Nasution, 1996; Soegijoko, 1996).

However, with the explosion of FDI influx from East Asian countries from the late 1980s onwards, Jakarta alone was no longer able to accumulate this vast amount of incoming investment. Indonesia's capital was facing limited land availability, rising costs of land and labour, and environmental issues (Henderson, Kuncoro, \& Nasution, 1996). Consequently, both new and existing industrial activities were forced to locate and relocate towards Jakarta's outskirts. Among other instruments, two state interventions jointly played a pivotal role in enabling this decentralization of manufacturing. First, the development of three intercity toll-road corridors, built by a state-owned company in the 1980s: the southern (Jakarta-Bogor-Ciawi), eastern (Jakarta-Tangerang), and western (Jakarta-Bekasi-Cikampek) corridors. These toll-roads have provided a stimulating physical precondition for socio-economic deconcentration by connecting the peri-urban areas with Jakarta's downtown and with the country's major transportation hubs: Tanjung Priok Seaport and Soekarno-Hatta Airport. Second, the Presidential Decree 53/1989 (later amended by Presidential Decree 41/1996) on Industrial Estate provided the legal basis for private and foreign actors to take a more active role in developing and managing industrial estates. By utilizing the availability of large amounts of vacant and cheap land in Jakarta's outskirts, numerous private industrial estates started to flourish in the peri-urban areas, forming the currently existing ribbon-like spatial pattern along the western and mainly the eastern toll-road corridors (Hudalah, 2017). 
The outbreak of the 1997 AFC and the subsequent fall of President Soeharto led to fundamental political and economic reorientations in Indonesia. The implementation of Law 22/1999 on Regional Administrations and Law 25/1999 on Inter-Government Financial Balance in 2001 marked Indonesia's 'big bang' transformation from a highly centralized planning regime to a more nominally democratic and decentralized system. Consequently, a wide range of previously central government responsibilities and resources were devolved to the local- or city-level governments (Firman, 2009). This paradigm shift was expected to endorse a more 'balanced' development. As a corollary, it was envisioned to abandon the JMA bias and, in turn, to aim for a counterweight growth yielded from and by other cities and regions of the country (Miller, 2013).

However, in the early years of this new system's implementation, there was no clear national spatial policy released to support the vision of such a more 'balanced' urban system. So, although Law 24/1992 on Spatial Planning, still emphasizing centralization, was already issued, it was perceived to be no longer relevant to cope with the new decentralization atmosphere (Hudalah \& Woltjer, 2007). In practice, this spatial policy was already outdated vis-à-vis the new regulations produced to support the implementation of decentralization. Along with the absence of pertinent spatial policies, infrastructure development was also markedly hampered by the ongoing crisis (Firman, 2002). Accordingly, the state's spatial and physical intervention in the JMA's development tended to be invisible in the years following the AFC. Generally speaking, much effort was devoted to establish the new institutional set-up of the decentralized system as well as to recover the country's socio-economic conditions.

Although local states were given greater responsibilities in various policy fields including in spatial planning in this new decentralization era, the national state remains responsible for managing and guiding the overall development at the national level. Following the country's gradual economic recovery and political stability starting from the late 2000 s, the national state moreover has recently regained its attention on the nation's spatial development. This was exemplified by the issuance of two principal spatial policies: the Government Regulation 26/2008 on the National Spatial Plan (RTRWN) and the Presidential Regulation 32/2011 on the Masterplan for Acceleration and Expansion of Indonesia Economic Development (MP3EI). Interestingly, despite the earlier enthusiasm for balanced development, the spatial documents, especially the latter one, tend to reassert the preeminent position of the JMA within the national urban system. More specifically, according to the MP3EI, the JMA, together with the Surabaya metropolitan area (the second largest economy of the country), are planned as the primary (non-resource-based) industrial centres of the country. Meanwhile, drawing on the country's existing geo-economic potential, other regions, mainly outside Java, are designated as centres for agricultural-, mining and oil-, or tourism-based economy. In addition, the JMA is planned to further establish itself as the main (if not only) service centre of the country. In other words, although the MP3EI values the geographical diversity among regions and 
aspires more inter-regional equalities, it basically supports the most value-adding and knowledgeintensive activities to be located in and around major cities, most notably the JMA. In addition, it remains to be seen whether local states are able to creatively foster their own urban and regional development, including attracting FDI, in order to potentially counterpoise the JMA's longestablished dominance. As Firman (2009) notes, the outcome of the decentralization policy seems to be patchy as the success of urban-regional development greatly depends on the ability of the local leaders to effectively steer and govern the local development processes (see Bunnell et al., 2013).

Along with these spatial policies, one can observe that recent strategic large-scale urban megaprojects, initiated by the national state, exhibit a tendency for privileging the JMA. For instance, a project of fibre optic networks has chosen the JMA, together with the Surabaya metropolitan area, as its initial project locations (Sari, 2015), putting other urban regions in the country further behind. The development of Jakarta's metro system (the first metro system project in the country) and a sizable expansion of the Soekarno-Hatta Airport are other conspicuous examples. Although these megaprojects are not directly planned to expand, for instance, manufacturing industries, the improvement of infrastructure quality and capacity can lead to bigger advantages for the JMA in order to attract a larger amount of people, goods, and capital, thus indirectly resulting in a more intensive urban-industrial agglomeration (see Peck, 1996).

Overall, in the decentralization era, which effectively started from the second half of the 2000s onwards, it is obvious that the national state intervention has privileged the JMA to remain the prime location for the country's most-advanced economic activities. This situation aptly resembles what Jones (1997) calls 'spatial selectivity'. However, with the pervasive rise of a neoliberal and democratic agenda, the national state tends to play an indirect role by enacting principal regulations and initiating strategic infrastructural projects. This agenda has resulted in greater opportunities for other actors, including those in the private sector, to be involved in urban and regional development. Consequently, and similar to other democratized emerging East Asian countries such as the Philippines (Shatkin, 2008), large private developers, both domestic and foreign ones, have played an active role in carrying out global aspirational projects by developing new towns and industrial estates in the JMA. In this regard, Bekasi counts as one of the prime examples. By contrast, in China's socialist system, the national and local states play a significantly larger role by acting both as the key entrepreneurs and developers (Wu \& Barnes, 2008).

\section{Implications for the JMA's transformation as a GCR}

The national state has clearly affected the dispersion of FDI influx into the JMA. These global and local factors have in turn shaped the trajectory and pattern of the JMA's urban development as a 
GCR. Consequently, the JMA has managed to persist as Indonesia's growth machine despite the country's previous institutional transition from a centralized regime towards a democratic and decentralized political system. In fact, on the basis of GDP, the JMA's dominance in the national economy has increased slightly from 23\% in 1993 to 24\% in 2012 (BPS, various years). In particular, and similar to other major metropolises in East Asian emerging economies (Wei, Leung, \& Luo, 2006), the industrial sector remains as a key sector that generates the JMA's urban dynamism. At the national level, the JMA remains to be Indonesia's hotspot for manufacturing investment (Hudalah, 2017) and hosts the largest concentration of industrial estates (15,686 ha) in the country (HKI, 2016). Accordingly, this metropolis has continuously been the biggest contributor (i.e. about a quarter) to the national GDP in manufacturing over the last two decades (BPS, various years).

Friedmann (1986) argued in his seminal 'world city hypothesis' that the deepening global integration and the economic globalization process of a metropolis is manifest in its internal restructuring. In the case of the JMA, this restructuring is typified by what Scott et al. (2001: 18) call 'a simultaneous and complex process of decentralization and recentralization'. Following the decentralization of manufacturing FDI within the JMA, the city of Jakarta itself has experienced a gradual deindustrialization process, notably represented by its shifting geographical pattern in terms of GDP and labour (Table 1). This has also been followed by a population and residential spillover to the periurban areas, driven by both private and public interventions, as the overall carrying capacity of Jakarta has reached its saturation point (Firman, 2004; Winarso \& Firman, 2002). This deconcentration of economic activities and the population can be regarded as a suburbanization process that took place in the JMA. Portrayed through the lens of land use dan land cover changes, starting from the late 1980s, extensive land use conversion (mainly from agriculture to built-up areas) have taken place in the nowperi-urban areas, indicating rapid physical urban expansion towards Jakarta's outskirts (Pribadi \& Pauleit, 2015; Rustiadi et al., 2015). As a result, the peri-urban areas are emerging as the new urban development frontiers of the metropolis.

Maneepong and Webster (2008: 133) observe that 'peri-urban areas at the edge of metropolitan system in East Asia are the new "factories of the world". Within the wide-spreading suburbanization process, Bekasi has above all emerged as the industrial heartland of the JMA, and thus Indonesia (Table 1). Following the spatial-sectoral dispersion pattern of incoming FDI, Bekasi has come into being as a centre of varying capital- and technology-intensive industries, such as the automotive, electronics, and chemical sectors. It is worth noting that Cikarang, the main industrial concentration in Bekasi, alone contributed about $46 \%$ of the national manufacturing export (Hudalah \& Firman, 2012). It is therefore unsurprising that the economic rise of Bekasi has in turn affected the overall economic performance of the peri-urban areas. For instance, the peri-urban's share in the JMA's total GDP gradually increased from 25\% in 1993 to $30 \%$ in 2012, of which Bekasi contributed nearly a half by 
2012. In addition, the emergence of Bekasi as the present-day globally-linked industrial powerhouse does not necessarily lead to the demise of the earliest industrial concentrations, such as in North and East Jakarta. However, some other traditional industrial centres in Jakarta's outskirts, most notably in Bogor Municipality, have ceased to exist due to the diminishing competitiveness of several 'older' industrial sectors in Indonesia, such as the textile industry.

On the other hand, the services sector, especially different kinds of producer services, has increasingly concentrated in Jakarta's CBD (Table 1). As Indonesia's capital city, Jakarta is traditionally the main service centre (i.e. governmental, commercial and trade, logistic, communication, financial, and business services) of the country (Silver, 2008; see also Taylor \& Derudder, 2016: 179-186). With the integration of the JMA into the global production networks in the late 1980s and the further revival of manufacturing industries since the end of the 2000s, Jakarta's specific role in services provision has been reconsolidated. In this sense, as the globally-linked manufacturing sector has continuously developed and expanded within the JMA, it simultaneously needs producer services to deal with the complex production and distribution process at the global, national, and regional levels (see Maulida, 2007). Jakarta's CBD, in particular, has been long established as a prime location for various forms of high-level social and economic activities (Silver, 2008), thus providing agglomeration attraction for globally-oriented producer services to locate themselves within. It should be noted, though, that this growth of the services sector does not necessarily mean that the JMA directly resembles the main economic features of GCRs in advanced economies.

Table 1 Socio-economic change in the JMA

\begin{tabular}{|c|c|c|c|c|c|c|c|c|c|c|}
\hline & \multirow{2}{*}{\multicolumn{2}{|c|}{$\begin{array}{c}\text { Population } \\
\text { Distribution } \\
(\%)\end{array}$}} & \multirow{3}{*}{$\begin{array}{l}\text { Population } \\
\text { Growth (\%) } \\
\text { 1990-2010 }\end{array}$} & \multirow{3}{*}{$\begin{array}{l}\text { Manufacturing } \\
\text { Employment } \\
\text { Growth (\%) } \\
1995-2010\end{array}$} & \multicolumn{6}{|c|}{ GDP Distribution (\%) } \\
\hline & & & & & \multicolumn{2}{|c|}{ Total GDP } & \multicolumn{2}{|c|}{ Manufacturing } & \multicolumn{2}{|c|}{ Services } \\
\hline & 1990 & 2010 & & & 1993 & 2012 & 1993 & 2012 & 1993 & 2012 \\
\hline West Jakarta & 10.6 & 8.2 & 25.2 & - & 12.2 & 10.5 & 3.0 & 2.8 & 16.8 & 13.7 \\
\hline Central Jakarta & 6.3 & 3.2 & -16.9 & - & 18.6 & 18.6 & 1.4 & 0.8 & 26.8 & 27.0 \\
\hline South Jakarta & 11.2 & 7.4 & 7.8 & - & 17.0 & 16.0 & 0.6 & 0.9 & 23.9 & 21.5 \\
\hline East Jakarta & 12.1 & 9.6 & 30.3 & - & 13.3 & 11.9 & 18.4 & 13.0 & 11.6 & 11.7 \\
\hline North Jakarta & 8.0 & 5.9 & 20.2 & - & 14.2 & 13.1 & 24.1 & 19.0 & 10.5 & 10.4 \\
\hline Jakarta & 48.2 & 34.3 & 16.1 & -14.6 & 75.4 & 70.0 & 47.6 & 36.5 & 89.5 & 84.1 \\
\hline Bekasi District $^{\mathrm{a}}$ & 12.3 & 17.8 & 135.9 & - & 8.8 & 12.6 & 25.7 & 31.8 & 1.7 & 4.8 \\
\hline Bogor District $^{\mathrm{b}}$ & 21.8 & 23.3 & 74.2 & - & 8.1 & 7.0 & 14.0 & 14.4 & 3.8 & 3.4 \\
\hline Bogor Municipality & 1.6 & 3.4 & 249.8 & - & 0.5 & 0.9 & 0.3 & 0.9 & 0.5 & 0.9 \\
\hline Tangerang District ${ }^{\mathrm{c}}$ & 16.1 & 14.8 & 49.1 & - & 3.5 & 4.3 & 6.3 & 7.6 & 1.6 & 2.4 \\
\hline Tangerang Municipality & $0.0^{\mathrm{d}}$ & 6.4 & - & - & 3.7 & 5.28 & 6.1 & 8.8 & 3.0 & 4.4 \\
\hline Peri-urban & 51.8 & 65.7 & 106.7 & 16.8 & 24.6 & 30.0 & 52.4 & 63.5 & 10.5 & 15.9 \\
\hline JMA & 100 & 100 & 63.0 & 4.7 & 100 & 100 & 100 & 100 & 100 & 100 \\
\hline
\end{tabular}

Source: Calculated from BPS (various years) and Hudalah et al. (2013) 


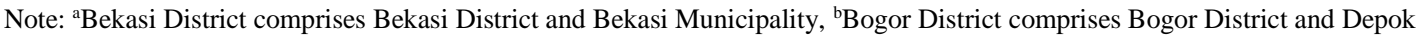

Municipality, ${ }^{\mathrm{c}}$ Tangerang District comprises Tangerang District and South Tangerang Municipality, ${ }^{\mathrm{d}}$ Population data of Tangerang Municipality in 1990 is merged with Tangerang District

\section{Conclusions}

Not unlike many other major cities in developing economies, the influx of FDI has been a fundamental external force that has generated and restructured the urban spatial economy of the JMA. Our paper has shown how the influx of FDI into the JMA is prone to changes in the global economy, including the abrupt 1997 AFC. This suggests that urban development and internal restructuring of the JMA in the last three decades is a part of, and has been continually reshaped by the dynamics of the capitalist global economy, mainly within the context of East Asian economic dynamics. However, our discussion has shown that this does not imply a simple cause-and-effect connection between 'global' economic changes and urban transformation. FDI itself has shifted in terms of source countries and sectoral constitution, but above all: the national state has played a pivotal and complementing role in this process through preferential spatial and sectoral policies and facilitating strategic urban (infrastructural) megaprojects, privileging the JMA. In this sense, the JMA's transformation should not only be regarded as the spatial 'outcome' of the global economy, but also the result of a national state that uses and privileges its major urban drawing card to strengthen the global competitiveness of the national economy as a whole. Our discussion clearly indicates that despite the changing political system, the JMA has been continuously considered to be the focal location for the country's most strategic national economic sectors (i.e. capital and technology-intensive industries), and most recently infrastructural urban megaprojects (i.e. transportation and communication projects).

On the urban and regional level, similar to what has been experienced in other GCRs in East Asian developing and industrializing countries (Une, 2015; Zhao \& Zhang, 2007), an intra-regional functional division of labour has emerged within the JMA. In this respect, while the manufacturing industry remains the key sector generating the JMA's urban dynamism, it has gradually decentralized from Jakarta towards its outskirts. This process, together with residential and population decentralization, has promoted a rapid peri-urbanization with a speed, scale, and complexity greatly differing from that experienced before the early 1990s (Rustiadi et al., 2015). At the same time, the traditional metropolis core, notably the $\mathrm{CBD}$, has gradually specialized as a services centre. It is the primary location of diverse kinds of producer services and many corporate headquarters that have played a pivotal part in the rapid urbanization and industrialization of the JMA.

\section{References}

BKPM [Indonesia Investment Coordinating Board] (2015). Realized investment data in Indonesia. Retrieved from http://nswi.bkpm.go.id/wps/portal (accessed 20 July 2015). 
BPS [Indonesia Statistical Office] (various years). Municipalities/Districts in Figures. Jakarta: BPS.

Bunnell, T., Miller, M. A., Phelps, N. A., \& Taylor, J. (2011). Urban development in a decentralized Indonesia: Two success stories? Pacific Affairs, 86(4), 857-876.

Derudder, B., Hoyler, M., Taylor, P. J., \& Witlox, F. (Eds.) (2012). International Handbook of Globalization and World Cities. Cheltenham, UK \& Northampton, MA: Edward Elgar.

Dicken, P. (2011). Global Shift: Mapping the Changing Contours of the World Economy. $6^{\text {th }}$ Ed. New York \& London: Guilford Press.

Douglass, M. (2000). The rise and fall of world cities in the changing space-economy of globalisation: Comment on Peter J. Taylor's 'world cities and territorial states under conditions of contemporary globalisation.' Political Geography, 19(1), 43-49.

Firman, T. (1998). The restructuring of Jakarta Metropolitan Area: A "global city" in Asia. Cities, 15(4), 229-243.

Firman, T. (2002). Urban development in Indonesia, 1990-2001: From the boom to the early reform era through the crisis. Habitat International, 26(2), 229-249.

Firman, T. (2004). New town development in Jakarta Metropolitan Region: A perspective of spatial segregation. Habitat International, 28(3), 349-368.

Firman, T. (2009). Decentralisation reform and local-government proliferation in Indonesia: Towards a fragmentation of regional development. Review of Urban and Regional Development Studies, 21(2-3), 143-157.

Florida, R., Gulden, T., \& Mellander, C. (2008). The rise of the mega-region. Cambridge Journal of Regions, Economy, and Society, 1(3), 459-476.

Friedmann, J. (1986). The world city hypothesis. Development and Change, 17(1), 69-83.

Hamanaka, S. (2011). FDI in services and regional services and investment agreements: Examination of the Singapore shift in Japan's FDI into ASEAN. ADBI Working Paper 267. Tokyo: Asian Development Bank Institute.

Harrison, J., \& Hoyler, M. (Eds.) (2015). Megaregions: Globalisation's New Urban Form? Cheltenham, UK and Northampton, MA: Edward Elgar.

Henderson, J. V., Kuncoro, A., \& Nasution, D. (1996). The dynamics of Jabotabek development. Bulletin of Indonesian Economic Studies, 32, 71-95.

Hill, H. (1988). Foreign Investment and Industrialization in Indonesia. Singapore: Oxford University Press.

Hill, H. (1999). The Indonesian Economy in Crisis: Causes, Consequences and Lessons. Singapore: Institute of Southeast Asian Studies.

Hill, R. C., \& Kim, J.-W. (2000). Global cities and developmental states: New York, Tokyo and Seoul. Urban Studies, 37(12), 2167-2195.

Hudalah, D. (2017). Governing industrial estates on Jakarta's peri-urban fringe: From shadow government to network governance. Singapore Journal of Tropical Geography, 38(1), 58-74. 
Hudalah, D., \& Firman, T. (2012). Beyond property: Industrial estates and post-suburban transformation in Jakarta Metropolitan Region. Cities, 29(1), 40-48.

Hudalah, D., Viantari, D., Firman, T., \& Woltjer, J. (2013). Industrial land development and manufacturing deconcentration in Greater Jakarta. Urban Geography, 34(7), 950-971.

Hudalah, D., \& Woltjer, J. (2007). Spatial planning system in transitional Indonesia. International Planning Studies, 12(3), 291-303.

Jones, G. W., \& Douglass, M. (Eds.) (2008). Mega-Urban Regions in Pacific Asia: Urban Dynamics in a Global Era. Singapore: NUS Press.

Jones, M. R. (1997): Spatial selectivity of the state? The regulationist enigma and local struggles over economic governance. Environment and Planning A, 29(5), 831-864.

Kloosterman, R. C., \& Lambregts, B. (2007). Between accumulation and concentration of capital: Toward a framework for comparing long-term trajectories of urban systems. Urban Geography, 28(1), 54-73.

Kwanda, T. (2000). Pengembangan kawasan industri di Indonesia [Industrial estate development in Indonesia]. Dimensi Teknik Arsitektur, 28, 54-61.

Lipsey, R. E., \& Sjöholm, F. (2011). Foreign direct investment and growth in East Asia: Lessons for Indonesia. Bulletin of Indonesian Economic Studies, 47(1), 35-63.

Lo, F.-C., \& Yeung, Y.-M. (Eds.) (1996). Emerging World Cities in Pacific Asia. Tokyo: United Nations University Press.

Maneepong, C., \& Webster, D. (2008). Governance responses to emerging peri-urbanisation issues at the global-local nexus: The case of Ayutthaya, Thailand. International Development Planning Review, 30(2), 133-154.

Maulida, R. (2007). Analisis keterkaitan ekonomi sektoral dan spasial di DKI Jakarta dan Bodetabek: Pendekatan model I-O interregional [Analysis of sectoral and spatial linkage in Jakarta and Bodetabek: Interregional I-O approach]. Master Thesis. Department of Regional and Rural Development Planning, Bogor Agricultural University.

Miller, M. A. (2013). Decentralizing Indonesian city spaces as new 'centers'. International Journal of Urban and Regional Research, 37(3), 834-848.

MOI [Ministry of Industry] (2016). National export data based on sector. Retrieved from http://www.kemenperin.go.id/statistik/peran.php?ekspor=1 (accessed 12 August 2016).

Olds, K., \& Yeung, H. W.-C. (2004). Pathways to global city formation: A view from the developmental city-state of Singapore. Review of International Political Economy, 11(3), 489521.

Pain, K. (2008). Examining ‘core-periphery' relationships in a global city-region: The case of London and South East England. Regional Studies, 42(8), 1161-1172.

Pain, K. (2012). Spatial transformations of cities: Global city-region? Mega-city region? In Derudder, B., Hoyler, M., Taylor, P. J., \& Witlox, F. (Eds.), International Handbook of Globalisation and 
World Cities, 83-96. Cheltenham, UK \& Northampton, MA: Edward Elgar.

Peck, F. W. (1996). Regional development and the production of space: The role of infrastructure in the attraction of new inward investment. Environment and Planning A, 28(2), 327-339.

Pribadi, D. O., \& Pauleit, S. (2015). The dynamics of peri-urban agriculture during rapid urbanization of Jabodetabek Metropolitan Area. Land Use Policy, 48, 13-24.

Roy, A. (2009). The 21st-century metropolis: New geographies of theory. Regional Studies, 43(6), 819-830.

Rustiadi, E., Pribadi, D. O., Pravitasari, A. E., Indraprahasta, G. S., \& Iman, L. S. I. (2015). Jabodetabek megacity: From city development toward urban complex management aystem. In Singh, R. B. (Ed.), Urban Development Challenges, Risks and Resilience in Asian Mega Cities, 421-445. Tokyo: Springer.

Sari, E. V. (2015). Investor telekomunikasi Singapura siap tanam Rp 2 Triliun [Singaporean investors ready to invest IDR 2 trillion in telecommunication]. Retrieved from http://www.cnnindonesia.com/ekonomi/20151206004452-78-96234/investor-telekomunikasisingapura-siap-tanam-rp-2-triliun/ (accessed 01 January 2016).

Scott, A. J. (2001a). Globalization and the rise of city-regions. European Planning Studies, 9(7), 813826.

Scott, A. J. (2001b). Introduction. In Scott, A. J. (Ed.), Global City-Regions: Trends, Theory, Policy, 1-8. New York: Oxford University Press.

Scott, A. J., Agnew, J., Soja, E. W., \& Storper, M. (2001). Global city-regions. In Scott, A. J. (Ed.), Global City-Regions: Trends, Theory, Policy, 11-32. New York: Oxford University Press.

Sedyawati, E., Rahardjo, S., Johan, I. M., \& Manilet-Ohorella, G. A. (1986). Sejarah Kota Jakarta 1950-1980 [the History of Jakarta 1950-1980]. Jakarta: Departemen Pendidikan dan Kebudayaan.

Shatkin, G. (2008). The city and the bottom line: Urban megaprojects and the privatization of planning in Southeast Asia. Environment and Planning A, 40(2), 383-401.

Silver, C. (2008). Planning the Megacity: Jakarta in the Twentieth Century. Oxfordshire: Routledge.

Sit, V. F. S. (2001). Globalisation, foreign direct investment, and urbanization in developing countries. In Yusuf, S., Evenett, S. J., \& Wu, W. (Eds.), Facets of Globalisation: International and Local Dimensions of Development, 11-46. Washington: World Bank.

Soegijoko, B. T. (1996). Jabotabek and globalisation. In Lo, F.-C., \& Yeung, Y.-M. (Eds.), Emerging World Cities in Pacific Asia, 377-414. Tokyo: United Nations University Press.

Taylor, P. J., \& Derudder, B. (2016). World City Network: A Global Urban Analysis. $2^{\text {nd }}$ Ed. Oxon \& New York: Routledge.

Taylor P. J., Derudder, B., Hoyler, M., \& Ni, P. (2013). New regional geographies of the world as practised by leading advanced producer service firms in 2010. Transactions of the Institute of British Geographers, 38(3), 497-511. 
Taylor, P.J., Derudder, B., Faulconbridge, J., Hoyler, M., \& Ni, P. (2014). Advanced producer service firms as strategic networks, global cities as strategic places. Economic Geography, 90(3), 267291.

Thee, K. W. (2005). The development of labour-intensive garment manufacturing in Indonesia. Journal of Contemporary Asia, 39(4), 562-578.

Thee, K. W. (2000). The impact of the economic crisis on Indonesia's manufacturing sector. The Developing Economies, 38(4), 420-453.

Thomsen, S., Otsuka, M., \& Lee, B. (2011). The evolving role of Southeast Asia in global FDI flows. Asie.Visions No. 40, June 2011. Paris \& Brussels: Institut Français des Relations Internationales (IFRI).

Tijaja, J., \& Faisal, M. (2014). Industrial policy in Indonesia: A global value chain perspective. ADB Economic Working Paper Series No. 411, October 2014. Metro Manila: Asian Development Bank.

UNCTAD [United Nations Conference on Trade and Development] (2015). World Investment Report 2015. Geneva: United Nations Publication.

Une, Y. (2015). Spatial dynamics of the automobile industry in the extended Bangkok metropolitan region. In Singh, R. B. (Ed.), Urban Development Challenges, Risks and Resilience in Asian Mega Cities, 409-420. Tokyo: Springer.

Urata, S. (1993). Japanese foreign direct investment and its effect on foreign trade in Asia. In Ito, T., \& Krueger, A. O. (Eds.), Trade and Protectionism, NBER-EASE Volume 2, 273-304. Chicago: University of Chicago Press.

van der Eng, P. (1998). Exploring exploitation: The Netherlands and colonial Indonesia 1870-1940. Revista de Historia Ecónomica, 16(1), 291-321.

Wall, R. S., \& van der Knaap, G. A. (2011). Sectoral differentiation and network structure within contemporary worldwide corporate networks. Economic Geography, 87(3), 267-308.

Wei, Y. D., Leung, C. K., \& Luo, J. (2006). Globalizing Shanghai: Foreign investment and urban restructuring. Habitat International, 30(2), 231-244.

Winarso, H., \& Firman, T. (2002). Residential land development in Jabotabek, Indonesia: Triggering economic crisis? Habitat International, 26(4), 487-506.

World Bank (2012). Agglomeration and manufacturing activities in Indonesia. Policy Note 6: 73127. Jakarta: World Bank.

Wu, J., \& Barnes, T. (2008). Local planning and global implementation: Foreign investment and urban development of Pudong, Shanghai. Habitat International, 32(3), 364-374.

Yang, X., Derudder, B., Taylor, P. J., Ni, P., \& Shen, W. (2017). Asymmetric global network connectivities in the world city network, 2013. Cities, 60(A), 84-90.

Yeung, H. W.-C., Poon, J., \& Perry, M. (2001). Towards a regional strategy: The role of regional headquarters of foreign firms in Singapore. Urban Studies, 38(1), 157-183. 
Zhao, S. X. B., \& Zhang, L. (2007). Foreign direct investment and the formation of global cityregions in China. Regional Studies, 41(7), 979-994. 